DOI: 10.2478/aucft-2013-0004

\title{
CONTENT VARIATION OF IRON AND COPPER IN WINE OBTAINED FROM WINE VINEYARDS RECAŞ
}

— short communication -

\author{
Otto KETNEY ${ }^{1}$, Ecaterina LENGYEL, Ovidiu TITA, Anca ȚIFREA \\ "Lucian Blaga” University of Sibiu, Faculty of Agricultural Sciences, Food \\ Industry and Environmental Protection, Sibiu, Romania
}

\begin{abstract}
Wine grapes are brought to the center in baskets, plastic containers, wooden bene, or more modern like metal bene. From picking and transport can be transmitted to grapes, the iron or copper from all equipment on metal and after will be transmitted also to wines produced. It must therefore control of how was made the insulation of protective metal bene to avoid contact the metal with grapes. The aim of this work involves evaluating the content of iron and copper in wines and vineyards of Recass. The results indicated that the values determined by methods Photocolorimeters were within normal limits and revealed that the level of iron and copper in samples analyzed were not influenced by the process or storage conditions.
\end{abstract}

Keywords: Iron , Copper, wine

\section{INTRODUCTION}

Wine is a beverage consumer with a tradition of thousands of years. The composition of wine is influenced by many factors related to the specific production area: grape varieties, soil and climate, and viticulture practices (Baluja-Santos and Gonzalez-Portal, 1992, Augagneur et al., 1996) (Frank and Kowalski, 1984) (Pérez-Jordán et al., 1999)

${ }^{1}$ Corresponding author. Mailing adress: University "Lucian Blaga" of Sibiu, Faculty of Agricultural Sciences, Food Industry and Environmental Protection, 7-9 Ion Raţiu street, 550012 Sibiu, Romania. Phone: 0040/269/211338. Fax: 0040269212558. EMail: otto_ketney@yahoo.com

Acta Universitatis Cibiniensis Series E: FOOD TECHNOLOGY

Vol. XVII (2013), no. 1 
Banat vineyard comprises several vine centers: Recaş, Buziaş, Tirol, Teremia and Moldova Noua (Brad et al., 2009). Recas wine center is located at a distance of $21 \mathrm{~km}$ from Timişoara, $37 \mathrm{~km}$ from Lugoj national road DN6 (European E70) (Wikipedia, 2013) . The environmental conditions of this region are put in value by there varieties of wine grapes of high quality such as: Cabernet Sauvignon, Pinot Noir, Merlot, Burgund, and those for white superior wine: Pinot, Riesling Italian, Fetească regale, Sauvignon and Chardonnay (Savescu et al., 2006).

Iron content in wines is an important parameter controlling the quality and stability of wines (Tašev et al., 2006). Metal ions such as iron (Oszmianski et al. 1996) or copper (Scollary 1997) much enhance browning of catechin in wine-like medium containing tartaric acid due to the formation of xanthylium pigments . Normally, in fermented wines the main part of Fe is present in the form of ferrous ions, $\mathrm{Fe}$ (II), while the content of ferric ions, Fe(III), is much lower. When wine is exposed to air during a further enological treatment, $\mathrm{Fe}$ (II) ions can be readily oxidized to $\mathrm{Fe}$ (III) form and a wine spoilage may be activated (Pohl and Prusisz, 2009). Addition of potassium hexacyanoferrate(II) eliminates part of iron content and significantly decreases concentration of other metals that also participate in the browning of white wines (Oszmianski et al., 1996).

Copper is one of the most important biopesticides used in organic farms. It is effective against a high number of crops pests and it is utilized as a fungicide, a bactericide and also as a herbicide (Provenzano et al., 2010). The main source of copper in finished product is a consequence of the practice of $\mathrm{CuSO} 4$ addition for the removal of hydrogen sulfide and other sulfidic off-odors (Pyrzyńska, 2004).

The present work is aimed at establishing the copper and iron content in wines from the Recas province (Romania)

\section{MATERIALS AND METHODS}

\section{Samples description}

Coding samples was done after the grape varieties musts were obtained as follows:

- MO sample was obtained from Ottonel Muscat grapes - aromatic variety, harvested fully ripe in the vineyard Recaş, 2012. Sugar content was $215 \mathrm{~g} / \mathrm{L}, \mathrm{pH} 3.6$, and acidity of 4.6. Technological process was characterized by:

Vol. XVII (2013), no. 1 
o pellicular maceration enzyme type Sihazym EXTRO for 12 hours at $15^{\circ} \mathrm{C}$

- sulphite pomace with aqueous $10 \mathrm{~g} / \mathrm{L}$

- CH sample was obtained from grapes harvested fully ripe Chardonnay from vineyards Recaş year average 2012. Sugar content was between $210-215 \mathrm{~g} / \mathrm{L}, \mathrm{pH} 3.29$ to 3.45 , and acidity between 5.3 to 7,6 . Technological process was characterized by:

o pellicular maceration enzyme type Sihazym EXTRO for 2 hours at $15^{\circ} \mathrm{C}$

- sulphite pomace with aqueous $10 \mathrm{~g} / \mathrm{L}$

- FR Sample was obtained from grapes Fetească royal vineyard harvested at full maturity of Recaş, 2012. Sugar content was between 215 - $225 \mathrm{~g} / \mathrm{L}, \mathrm{pH} 3.27$ to 3.35 , and acidity between 3.3 - 3.6. Technological process was characterized by:

o pellicular maceration enzyme type Sihazym EXTRO for 2 hours at $15^{\circ} \mathrm{C}$

○ sulphite pomace with aqueous $10 \mathrm{~g} / \mathrm{L}$

- SB Sample was obtained from grapes harvested fully ripe Sauvignon Blanc from vineyards Recaş year average 2012. Sugar content was between 209 - 221g / L, pH 3.25 to 3.38, and acidity between 5.1 7.2. Technological process was characterized by:

o pellicular maceration enzyme type Sihazym EXTRO for 2 hours at $15^{\circ} \mathrm{C}$

- sulphite pomace with aqueous $10 \mathrm{~g} / \mathrm{L}$

- CS Sample, was obtained from grapes harvested fully ripe Cabernet Sauvignon from Vineyard Recaş year average 2012. Sugar content was between 206 - 220g / L, pH 3.31 to 3.47, and acidity between 7.3 - 7.8. Technological process was characterized by:

o fermentation maceration enzyme type Sihazym EXTRO for 20 days at $15^{\circ} \mathrm{C}$,

- clarification by flotation

○ one to three days rework

- PN Sample was obtained from grapes harvested fully ripe Pinot Noir from vineyard Recaş year average 2012. Sugar content was between $211-222 \mathrm{~g} / \mathrm{L}, \mathrm{pH} 3.27$ to 3.45 , and the acidity from 7.1 - 7.5. Technological process was characterized by:

$\circ$ fermentation maceration enzyme type Sihazym EXTRO for 20 days at $15^{\circ} \mathrm{C}$,

Vol. XVII (2013), no. 1 
○ clarification by flotation

o one to three days rework

\section{Analyses}

Determination of iron. Was done by photocolorimeter method a with a colorimeter Hanna Instruments, model HI 83741, measuring principle and working stages were described by Hanna Instruments (2013b)

Determination of copper. Was done by photocolorimeter method a with a colorimeter Hanna Instruments, model HI 83740, measuring principle and working stages were described by Hanna Instruments (2013a)

\section{Statistical analyses}

Data were analysed, when necessary, by one-way analysis of variance (ANOVA). Significant differences were determined at a significance level equal to or lower than 5\%(p<5). An SPSS (Statistical Package for the Social Sciences) software version (IBM SPSS 20.0 for Windows) was used to carry out all statistical tests.

\section{RESULTS AND DISCUSSIONS}

There are various sources contributing to the metal composition of the finished wine (Scollary 1997). In the case of copper, the minimum values obtained were $0.08 \mathrm{mg} / \mathrm{L}$ for sample FR and maximum values were $0.34 \mathrm{mg}$ / L when the sample $\mathrm{CH}$. The main factors could be cupric treatments of vineyard before harvest rain and materials used in various technological operations, levels of oxidation-reduction during these operations. Wide ranges for copper concentration in wines have been previously found and reported by others including: $0.056-0.764 \mathrm{mg} / \mathrm{L}$ (Schiavo et al. 2008) ; $0.031-0.313 \mathrm{mg} / \mathrm{L}$ red Hungarian wines (Ajtony et al. 2008) ; 0.2-0.6 mg/L Greek wines (Galani-Nikolakaki et al. 2002); 0.347-0.487 mg/L Italians wines(Buldini et al. 1999).

Iron is found in substantial quantities in all grape and wine varieties (Lara et al. 2005). The main factors influencing the presence of exogenous sources of iron are ground and redox conditions during and after alcoholic fermentation, equipment and oenological practices used. In this case iron concentration was 1.24 when the minimum sample FR and maximum of $4.06 \mathrm{mg} / \mathrm{L}$ for sample PN.

Vol. XVII (2013), no. 1 


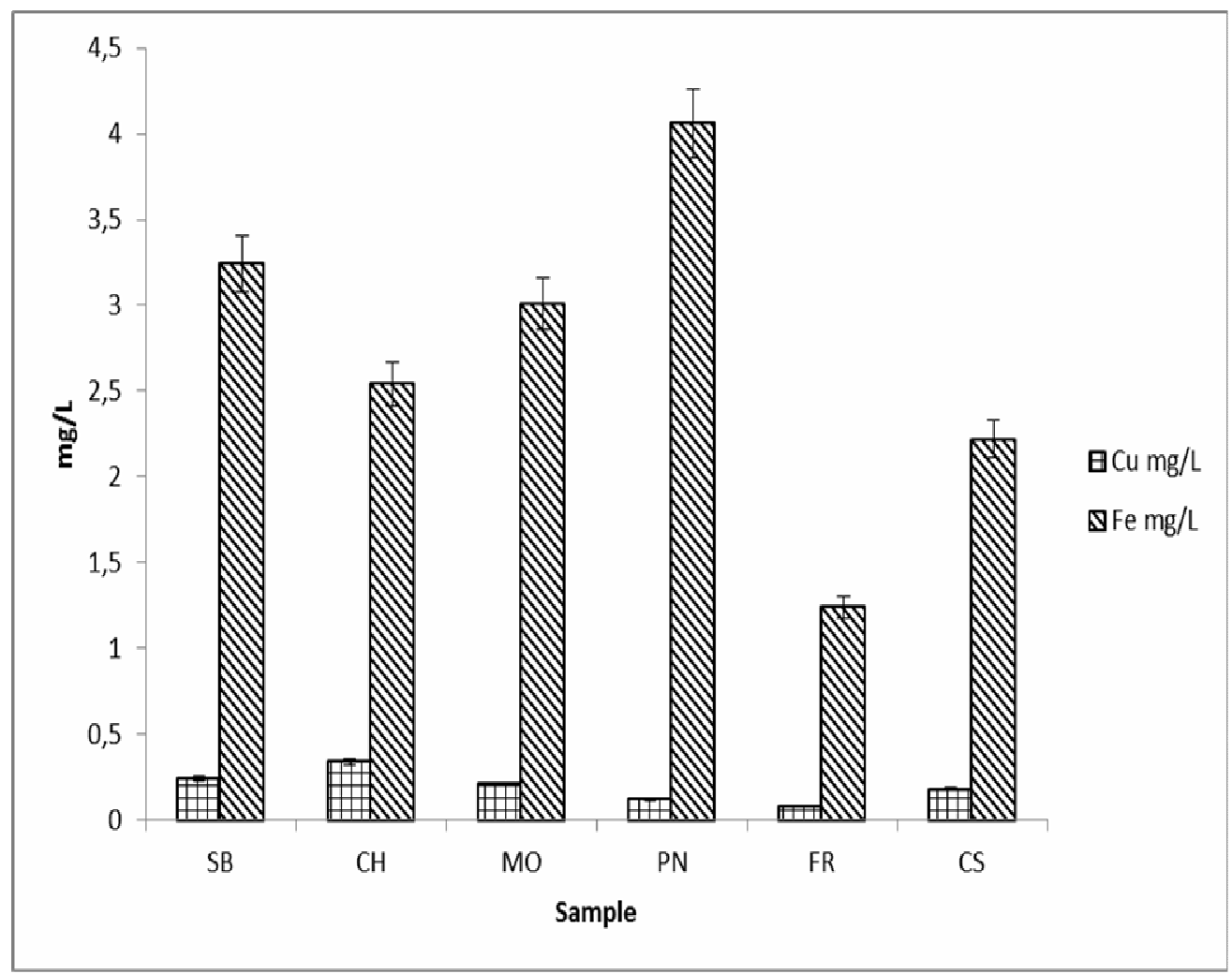

Figure 1. Iron and copper content of the analyzed samples

Results of the analysis of one-way ANOVA clearly demonstrate that there were no significant differences $(\mathrm{P}<0.05)$ between samples averages, most important variables were iron and copper samples SB and PN2 and lowest when the sample FR1

\section{CONCLUSIONS}

The conclusions derived from iron and copper analysis white wines through are:

- $\quad$ iron contents obtained for the Romanian wines have analysed Reported by agreeing with date literature.

- $\quad$ harvesting and technological processes do not influence the content of iron and copper

Vol. XVII (2013), no. 1 
- $\quad$ Iron levels can be directly influenced by the number of presses used to crush grapes, but it should be noted that pressing equipment are generally of iron or stainless steel they may also contribute to these levels

\section{REFERENCES}

1. Ajtony Z., Szoboszlai N., Suskó E. K., Mezei P., György K., Bencs L., Direct sample introduction of wines in graphite furnace atomic absorption spectrometry for the simultaneous determination of arsenic, cadmium, copper and lead content, Talanta, 2008, 76 (3), 627-634

2. Augagneur S., Médina B., Szpunar J., Lobiński R., Determination of rare earth elements in wine by inductively coupled plasma mass spectrometry using a microconcentric nebulizer, Journal of Analytical Atomic Spectrometry, 1996, 11 (9), 713-721

3. Baluja-Santos C., Gonzalez-Portal A., Application of hydride generation to atomic-absorption spectrometric analysis of wines and beverages: a review, Talanta, 1992, 39 (4), 329-339

4. Brad I., P. Iancu E. T., Toader C.-S., The analysis of areas and productions obtained in the wine field of Timis county, Lucrări Ştiinţifice, Universitatea de Stiinte Agricole Şi Medicină Veterinară" Ion Ionescu de la Brad" Iaşi, Seria Agronomie, 2009, 52 (2), 213-218

5. Buldini P. L., Cavalli S., Sharma J. L., Determination of transition metals in wine by IC, DPASV-DPCSV, and ZGFAAS coupled with UV photolysis, Journal of agricultural and food chemistry, 1999, 47 (5), 1993-1998

6. Frank I., Kowalski B. R., prediction of wine quality and geographic origin from chemical measurements by parital least-squares regression modeling, Analytica chimica acta, 1984, 162, 241-251

7. Galani-Nikolakaki S., Kallithrakas-Kontos N., Katsanos A., Trace element analysis of Cretan wines and wine products, Science of the total environment, 2002, 285 (1), 155-163

8. Hanna Instruments HI 83740 Copper ISM for wine analysis 2013a. Available from http://www.hannainst.com/manuals/manHI_83740.pdf.

9. Hanna Instruments HI 83740 Iron ISM for wine analysis 2013b. Available from http://www.hannainst.com/manuals/manHI_83741.pdf.

10. Lara R., Cerutti S., Salonia J., Olsina R., Martinez L., Trace element determination of Argentine wines using ETAAS and USN-ICP-OES, Food and Chemical Toxicology, 2005, 43 (2), 293-297

Vol. XVII (2013), no. 1 
11. Oszmianski J., Cheynier V., Moutounet M., Iron-catalyzed oxidation of (+)-catechin in model systems, Journal of agricultural and food chemistry, 1996, 44 (7), 1712-1715

12. Pérez-Jordán M. Y., Soldevila J., Salvador A., Pastor A., de la Guardia M., Inductively coupled plasma mass spectrometry analysis of wines, Journal of Analytical Atomic Spectrometry, 1999, 14 (1), 33-39

13. Pohl P., Prusisz B., Application of tandem column solid phase extraction and flame atomic absorption spectrometry for the determination of inorganic and organically bound forms of iron in wine, Talanta, 2009, 77 (5), 1732-1738

14. Provenzano M. R., El Bilali H., Simeone V., Baser N., Mondelli D., Cesari G., Copper contents in grapes and wines from a Mediterranean organic vineyard, Food Chemistry, 2010, 122 (4), 1338-1343

15. Pyrzyńska K., Analytical methods for the determination of trace metals in wine, Critical Reviews in Analytical Chemistry, 2004, 34 (2), 69-83

16. Savescu I. C., Goian M., Kocis E., Pedoclimatic characterization of recaş viticultural center caracterizarea pedoclimatică a centrului viticol Recaş. In Scientifical papers agriculture XXXVIII, edited by Agroprint. Agricultural and Veterinary University of the Banat ${ }^{\wedge}, 2006$.

17. Schiavo D., Neira J. Y., Nóbrega J. A., Direct determination of $\mathrm{Cd}, \mathrm{Cu}$ and $\mathrm{Pb}$ in wines and grape juices by thermospray flame furnace atomic absorption spectrometry, Talanta, 2008, 76 (5), 1113-1118

18. Scollary G., Metals in wine: contamination, spoilage and toxicity: Dossier: in vino analytica scientia, Analusis, 1997, 25 (3), M26-M30

19. Tašev K., Karadjova I., Arpadjan S., Cvetković J., Stafilov T.. Liquid/liquid extraction and column solid phase extraction procedures for iron species determination in wines, Food Control, 2006, 17 (6), $484-488$

20. Wikipedia. 2013. Recaș - Wikipedia 2013 [cited 14.03.2013 2013]. Available from http://ro.wikipedia.org/wiki/Recas.

Vol. XVII (2013), no. 1 